\section{Earthquake in Cyprus}

Further news has been received of the earthquake recently reported to have taken place on January 20 in Cyprus (Nature, February 1, p. 145). The epicentre of the earthquake appears from these latest reports to have been some five or six miles to the south of Famagusta. At Paralimmi, a village of 500 houses about 8 miles south of Famagusta, 50 houses were destroyed, 100 seriously damaged and four people were injured. Cracks and displacement of stones in large buildings and houses were widespread in the island, though no structure of importance collapsed. The Citadel, Mosque House, and Cathedral in Famagusta suffered damage, as also did Kyrenia Castle.

\section{Other Recent Earthquakes}

ON January 29 an earth tremor was experienced in Bucharest. It will be remembered that on November 10,1940 , a severe earthquake shook the city and the surrounding district, including the Rumanian oil field near Ploësti (NATURe, November 23, p. 675 ; 1940). Also on the evening of January 29 a severe earth tremor lasting 10 seconds according to human perception shook parts of California. No damage or casualties are so far reported.

Distant earthquakes were recorded at Kew Observatory on January 20, 21, and 24. The first, received at 3 h. $43 \mathrm{~m}$. 4s. G.M.T., may have occurred in Sicily. The first and second were recorded chiefly by the short-period instrument and the records were somewhat confused by microseisms.

The United States Coast and Geodetic Survey in co-operation with Science Service and the Jesuit Seismological Association has made a preliminary determination of the epicentre of the earthquake of November 23,1940 , at 3 h. $48 \mathrm{~m}$. 52s. G.M.T. Seismographic reports were received from the observatories at Manila, Huancayo, Pasadena, Philadelphia, Fordham, Burlington, Buffalo, and Tacubaya. From these reports the epicentre appeared to be near latitude $9^{\circ} \mathrm{N}$., longitude $84^{\circ} \mathrm{W}$., which is in the Pacific Ocean just off the coast of southern Costa Rica between Port Violín and Port Mala (Central America). This is in a well-known seismic zone.

On January 27 at about 3.20 a.m. local time an earthquake occurred with epicentre some 85-90 miles from Bergen in Norway. It is reported to have been the severest and nearest the locality has ever had, though no further details are available.

\section{Announcements}

The Council of the Institution of Electrical Engineers has elected the Right Hon. Sir Andrew Duncan to be an honorary member of the Institution. This distinction has been conferred upon Sir Andrew Duncan in appreciation of the outstanding services rendered by him to the electrical industry, particularly during his eight years of office as the first chairman of the Central Electricity Board. The Council has also made the nineteenth award of the Faraday Medal to Dr. A. P. M. Fleming, a pastpresident of the Institution. The Faraday Medal is awarded by the Council of the Institution not more frequently than once a year, either for notable scientific or industrial achievement in electrical engineering or for conspicuous service rendered to the advancement of electrical science, without restriction as regards nationality, country of residence, or membership of the Institution.

THE Council of the Royal Scciety of Edinburgh has awarded the Gunning Victoria Jubilee Prize for the period 1936-40 to Sir James Irvine, principal of the University of St. Andrews, for his distinguished contributions to organic chemistry; and the Macdougall Brisbane Prize for the period 1938-40, to Dr. E. L. Ince, Mathematical Institute, University of Edinburgh, for his papers on "The Perio:lic Lamé Functions", publishel in the Proceedings of the Society within the period of the award.

THe triennial award of the Coopers Hill War Memorial Prize and Medal, which fell in 1940 to the Institution of Electrical Engineers, has been made by the Council to Mr. J. S. Forrest, for his paper on "The Characteristics and Performance in Service of High Voltage Porcelain Insulators".

Prof. JAKOB SEILER, professor of special zoology in the Swiss Federal Institute of Teshnology, Zurich, has been elected a member of the Leopold Caroline Academy of Natural Science at Halle.

Prof. S. Chapman, professor of mathematics in the Imperial College of Science and Technology, will deliver the Kelvin Lecture of the Institution of Electrical Engineers on May 8; the subject of the lecture will be "Electrical Works by Helios, or the Sun and the Ionosphere". The council of the Institution has decided not to hold meetings of the Institution in London during the second half of the session. A list of some of the papers that would have been included has been issued and advance copies can be obtained from the secretary of the Institution.

THE following have been appointed officers of the Parliamentary and Scientific Committee for 1941: President: the Earl of Dudley; Vice-Presidenis: Capt. S. F. Markham, M.P., Viscount Samuel, Prof. A. V. Hill, F.R.S., M.P.; Chairman : Capt. I. F. Plugge, M.P.; Hon. Secretary : Dr. W. R. Wooldridge, National Veterinary Medical Association, Gordon Square, London, W.C.1 ; Secretary: Christopher Powell, Parliamentary and Scientific Committee, Courtfield House, 13 Courtfield Road, London, S.W.7.

According to the official report (Bol. Of. San. Panamer., 19, 936; 1940) the provisional vital st atistics for 1938 in the Argentine Republic are as follows: living births, 294,102 ; infantile mortality excluding the provinces of Santa Fé, Corrientes and Mendoza, 24,942 ; stillbirths, 9,188 ; population on December 31, 1938, 12,956,602 ; Federal Capital : births, 42,890; marriages, 21,046 ; deaths, 28,308 ; infantile mortality, 2,126 ; stillborn, 1,682 ; population, 2,345,221. In 1937, 288,161 living births were registered throughout the republic. The highest birth-rate was found in the provinces of Salta and the lowest in the Federal Capital and Province of Buenos Aires. 